\title{
Pengembangan Aplikasi Pengelolaan Proses Bisnis Dengan Metode Waterfall
}

\author{
Abdush Shomad Bukhori ${ }^{1)}$, M. Ainul Yaqin ${ }^{2)}$, dan Syahiduz Zaman ${ }^{3)}$ \\ ${ }^{1,2,3)}$ Teknik Informatika, Fakultas Sains dan Teknologi, UIN Maulana Malik Ibrahim Malang \\ Jalan Gajayana No.50, Dinoyo, Kota Malang, 65144, Indonesia \\ Email: shom0601@ gmail.com ${ }^{1)}$, yaqinov@ti.uin-malang.ac.id ${ }^{2}$, syahid@ti.uin-malang.ac.id ${ }^{3)}$
}

\begin{abstract}
Abstrak
Perkembangan teknologi informasi selaras dengan perkembangan dunia. Dunia yang sekarang dilanda pandemi harus dapat beradaptasi dengan penggunaan teknologi yang dapat membantu kebutuhan pelaku bisnis. Business Process Management (BPM) merupakan salah satu model pendekatan dalam membuat proses bisnis sedangkan Business Process Model Notation (BPMN) merupakan suatu standar dalam memodelkan proses bisnis dalam bentuk notasi. BPMN sering digunakan tetapi seringkali tidak dapat diimplementasikan secara langsung dalam sistem informasi yang digunakan. Dalam kondisi pandemi ini banyak masalah yang bermunculan, pelaku bisnis dituntut untuk dapat beradaptasi. Salah satunya adalah beradaptasi dengan kebiasaan dari customer yang berubah atau New Normal. Masalah lain yang sangat jelas adanya adalah penurunan omset dari bisnis. Hal ini membuat pelaku bisnis harus memikirkan cara agar tetap bisa bertahan dengan kondisi tersebut. Dengan hadirnya New Normal, customer akan lebih memilih untuk melakukan transaksi online. Sehingga pelaku bisnis harus membuat online platform untuk menjangkau customer dan atau melakukan proses-proses dalam bisnis mereka. Dengan kondisi omset yang menurun, biaya pembuatan online platform harus lebih ditekan. Business Proces Management System (BPMS) merupakan salah satu teknologi yang dapat mengimpelementasikan BPMN sesuai dengan model yang dibuat. BPMS merupakan solusi paling sesuai dengan permasalahan tersebut. Pada penelitian ini berhasil mengembangkan BPMS dengan metode Waterfall sehingga permasalahan-permasalahan tersebut dapat terselesaikan yaitu penerapan online platform yang tidak membebani keuangan karena perubahan-perubahan aplikasi dapat disesuaikan dengan proses bisnis yang diinputkan.
\end{abstract}

Kata kunci: Teknologi Informasi, Sistem Informasi, BPM, BPMN, Sistem BPM.

\section{Pendahuluan (Introduction)}

New Normal merupakan tantangan baru terhadap perkembangan serta pertumbuhan bisnis di seluruh penjuru dunia. Sebagai contoh nyata adalah banyak perkantoran atau tempat kerja yang menerapkan sistem kerja Work From Home (WFH). WFH diterapkan dengan tujuan mencegah penyebaran penularan virus COVID-19 secara langsung atau tak langsung (2020). Namun akhir-akhir ini memang sudah diperbolehkan pemerintah untuk bekerja di tempat kerja mereka dengan menaati protokol kesehatan yang sudah ditetapkan (2020). Tetapi pengawasan pegawai oleh atasan atau manajer tetap dilakukan baik pegawai yang bekerja onsite ataupun WFH.

Meskipun dari pengeluaran bisa saja sama ataupun lebih kecil, dengan menurunnya pendapatan bisa dipastikan keuntungan juga menurun yang berakibat banyaknya pegawai atau pekerja dirumahkan bahkan di-PHK. Hingga tanggal 27 Mei 2020, tercatat sebanyak lebih dari 3 juta pekerja telah di-PHK atau dirumahkan (Nasution, 2020).

Yuswohady, seorang pakar marketing, dalam situs resminya memprediksikan perubahan perilaku konsumen pada New Normal (Yuswohady, 2020). Beberapa prilaku tersebut adalah stay at home lifestyle dan go virtual. Akibatnya perusahaan harus melakukan pivot untuk menyesuaikan prilaku tersebut. Sehingga bisnis model yang digunakan pun juga akan berubah. 
Dampak yang terasa sangat jelas adalah penurunan pendapatan suatu usaha baik usaha kecil, menengah ataupun sebuah perusahaan. Ditunjukkan dengan data dari Badan Pusat Statistika (BPS) pada gambar 1 (Pusparisa, 2020).

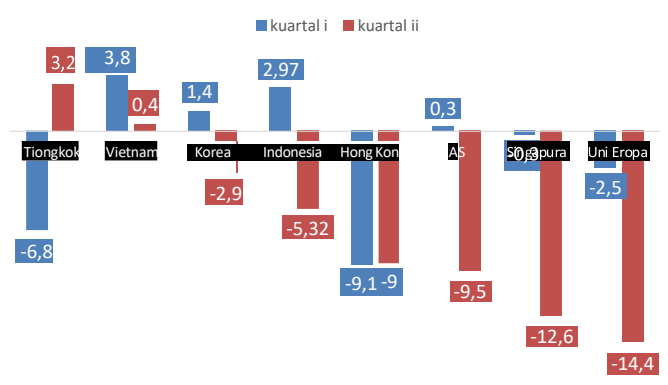

\section{Gambar 1. Pertumbuhan Ekonomi /PDB 2020 (YoY). Update 5 Agustus 2020}

Dengan menurunnya keuntungan, penerapan protokol kesehatan atau pun WFH yang memerlukan pengawasan kinerja pegawai secara realtime serta perubahan bisnis model dari perushaaan, mereka membutuhkan solusi yang tepat untuk menjawab ketiga permasalahan tersebut. Pengawasan kinerja pegawai secara realtime sudah pasti memerlukan sistem yang berbasis internet sesuai dengan setiap divisi perusahaan. Pembuatan sistem seperti itu akan memakan biaya yang sangat tinggi. Namun dengan pendapatan yang kurang baik, mereka harus menekan biaya dari pembuatan sistem tersebut.

Solusi paling tepat dari permasalahan-permasalahan tersebut adalah penerapan Manajemen Bisnis Proses (BPM). Dengan adanya BPM, perusahaan dapat menekan biaya pembuatan sistem informasi di setiap divisi, karena BPM memang mengarah pada kolaborasi lintas divisi. Sehingga sistem yang digunakan menjadi 1 kanal yang mana dapat digunakan dalam semua divisi. Perusahaan juga dapat melakukan pengawasan terhadap kinerja pegawai, karena BPM dapat meningkatkan kepatuhan dalam bekerja yang sering muncul karena kurang transparansi. Selain itu disertai pula dengan perubahan proses bisnis suatu perusahaan, BPM membantu dalam menyesuaikan proses bisnis yang digunakan ke dalam sistem yang dikembangkan (Henshall, 2019).

BPMS merupakan sistem yang dapat.membantu penggunanya menggunakan fitur-fitur sesuai dengan bisnis proses yang digunakan. Sehingga dalam kondisi apapun, pengguna tidak perlu khawatir akan perubahan dari sistemnya. Dikarenakan sistem dapat menyesuaikan dengan bisnis proses yang diinputkan. BPMS adalah sistem yang paling sesuai dalam menjadi solusi dari permasalahanpermasalahan tersebut.

Salah satu BPM Sistem yang populer menurut situs trustradius.com adalah Bonita BPM (TrustRadius). Bonita BPM adalah aplikasi berbasis website yang menggunakan framework dari javascript yaitu Angular JS. Fitur drag and drop pada form builder merupakan salah satu fitur unggulan mereka. Setiap aplikasi tidak akan luput dari ketidaksempurnaan. Salah satu pengguna dari Bonita BPM mengatakan bahwa "Sistem API BPM tidak memiliki keamanan dan semua pengguna yang diautentikasi dapat mengakses data tanpa batasan. Ini dapat memengaruhi keamanan data di berbagai departemen." (Zamfirescu, 2016).

Review tersebut adalah salah satu pengembangan lanjutan dari aplikasi yang dikembangkan oleh penulis. Keamanan data pada aplikasi akan lebih tertata sesuai dengan privillage masing-masing role user.

\section{Metode Penelitian}

XAMPP merupakan tools sederhana untuk menjalankan aplikasi berbasis website. Dalam tools tersebut telah disediakan web server dan juga database server yang mana merupakan dua komponen utamanya. 
Jenis web server yang digunakan adalah Apache/2.2.34 (Unix). Sedangkan jenis database server yang digunakan adalah MySQL 5.7.26 GPL Version. Penulis menggunakan Codeigniter Framework yang berbasis PHP sebagai server-side scripting serta client-side scripting. Black Box Testing digunakan sebagai metode dalam pengujian aplikasi yang dibangun, yaitu dengan menguji fitur atau modul yang dibangun pada aplikasi.

Dalam BPMS terdapat proses input bisnis proses yang mana dalam sistem yang dibangun ini menggunakan file XPDL versi 2 yang merupakan bahan utama dalam pengembangan aplikasi ini. File XPDL tersebut didapatkan dari proses export pada aplikasi Bizagi Modeler. Bizagi Modeler merupakan salah satu aplikasi yang dapat membantu dalam pembuatan bisnis proses. Bahan selanjutnya adalah web service yang mana merupakan komponen penting dalam penggunaan aplikasi.

File XPDL yang akan digunakan digambarkan pada gambar 2 sebagai squence process dan gambar 3sebagai branching process.

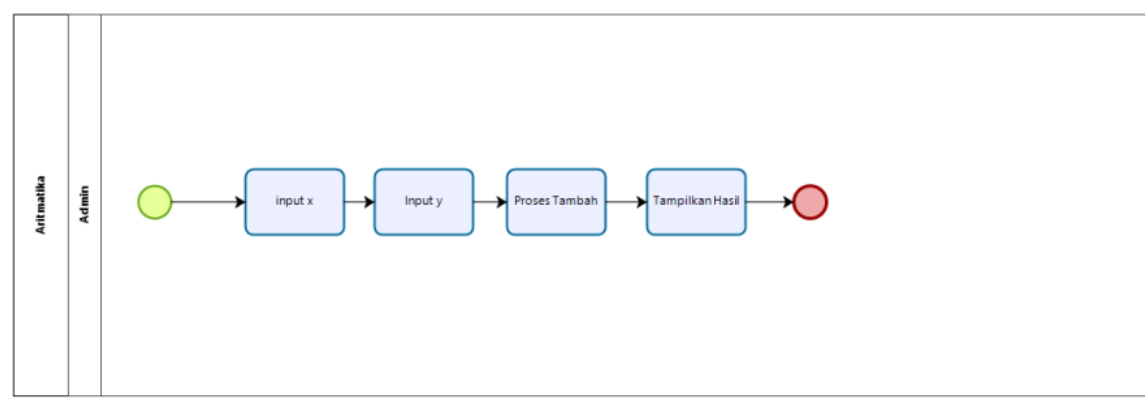

Gambar 2. Squence BPMN

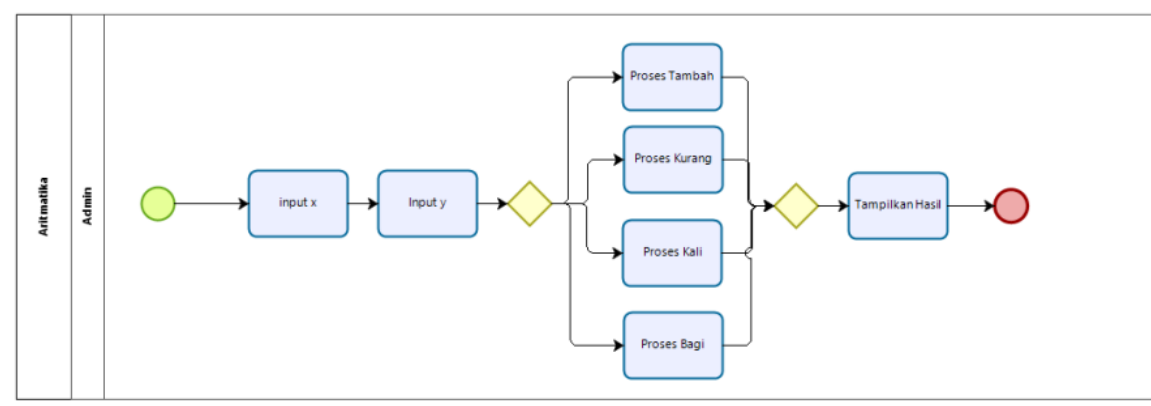

Gambar 3. Branching BPMN

Penulis menggunakan metode waterfall sebagai metode pengembangan aplikasi. Tahap-tahap dari metode tersebu antara lain: define/requirements, design, implementation/code, verification/test (Javanmard and Alian, 2015). Pada tahap requirements terdapat dua bagian yaitu fungsional dan nonfungsional. Requirements fungsional adalah fitur-fitur dari aplikasi (Nasrullah, 2021). Fitur yang disediakan dalam aplikasi berdasarkan table 1 antara lain:

Tabel 1. Tabel requirement fungsional

\begin{tabular}{cl}
\hline No & Requirement \\
\hline $\mathbf{1}$ & Aplikasi memiliki dua jenis user, yaitu superadmin dan admin tenant \\
$\mathbf{2}$ & Superadmin dapat mengelola semua data \\
$\mathbf{3}$ & Admin tenant hanya dapat mengelola data tenant sendiri \\
$\mathbf{4}$ & Tenant dapat mendaftar sendiri \\
$\mathbf{5}$ & Pengelolaan tenant \\
$\mathbf{6}$ & Pengelolaan web service \\
$\mathbf{7}$ & Pengelolaan user dan role user \\
$\mathbf{8}$ & Pengelolaan application \\
\hline \hline
\end{tabular}


$9 \quad$ Parsing XPDL

$10 \quad$ Mapping business process

Sedangkan requirements non-fungsional berdasarkan table 2 antara lain:

Tabel 2. Tabel requirement non-fungsional

\begin{tabular}{cl}
\hline No & Requirement \\
\hline $\mathbf{1}$ & Aplikasi dilengkapi dengan autentikasi per level user \\
$\mathbf{2}$ & Aplikasi dijalankan pada jaringan lokal, yaitu localhost \\
$\mathbf{3}$ & Aplikasi dijalankan dengan web browser \\
\hline
\end{tabular}

Pada tahap design, terdapat 4 aspek utama yaitu output, input, process dan database yang akandijelaskan pada table 3 .

Tabel 3. Tabel hubungan requirement dan design (output, input dan process)

\begin{tabular}{cccc}
\hline Requirement & Output & Process \\
\hline Tabel 1 no 1 & Login berdasarkan role masing-masing & Gambar 4 & Algoritma 1 \\
Tabel 1 no 2 & Gambar 5 & Session Data & Algoritma 2 \\
Tabel 1 no 3 & Gambar 6 & Session Data & Algoritma 3 \\
Tabel 1 no 4 & Terdaftar sebagai Admin Tenant & Gambar 7 & Algoritma 4 \\
Tabel 1 no 5 & Super Admin dapat mengelola Data Tenant & Gambar 8 & Algoritma 5 \\
Tabel 1 no 6 & Super Admin dapat mengelola Web Service & Gambar 8 & Algoritma 6 \\
Tabel 1 no 7 & Admin Tenant dapat mengelola User dalam Tenant & Gambar 8 & Algoritma 7 \\
Tabel 1 no 8 & Admin Tenant dapat mengelola Aplikasi dalam & Gambar 8 & Algoritma 8 \\
Tabel 1 no 9 & Tenant & Gambar 9 & Algoritma 9 \\
Tabel 1 no 10 & Proses Bisnis telah dipetakan dengan Web Service & Gambar 10 & Algoritma 10 \\
\hline
\end{tabular}

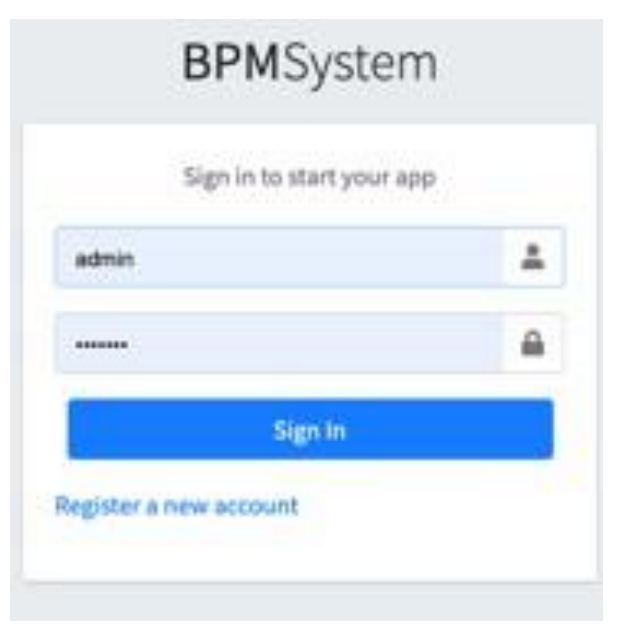

Gambar 4. Halaman Login 


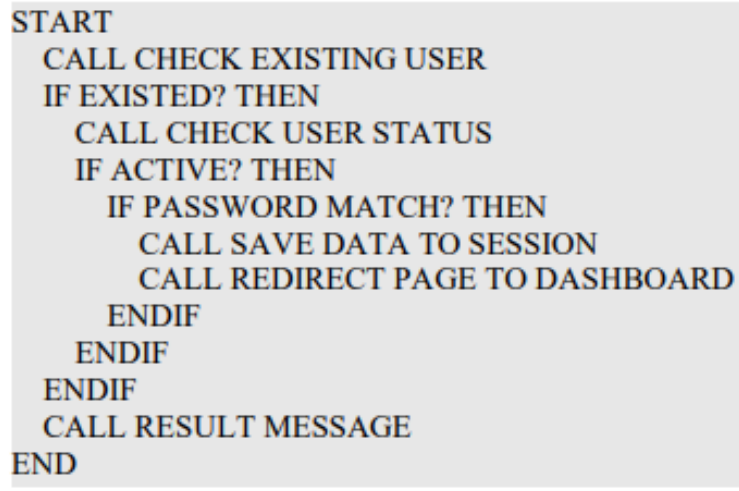

Algoritma 1. Pseudocode Login

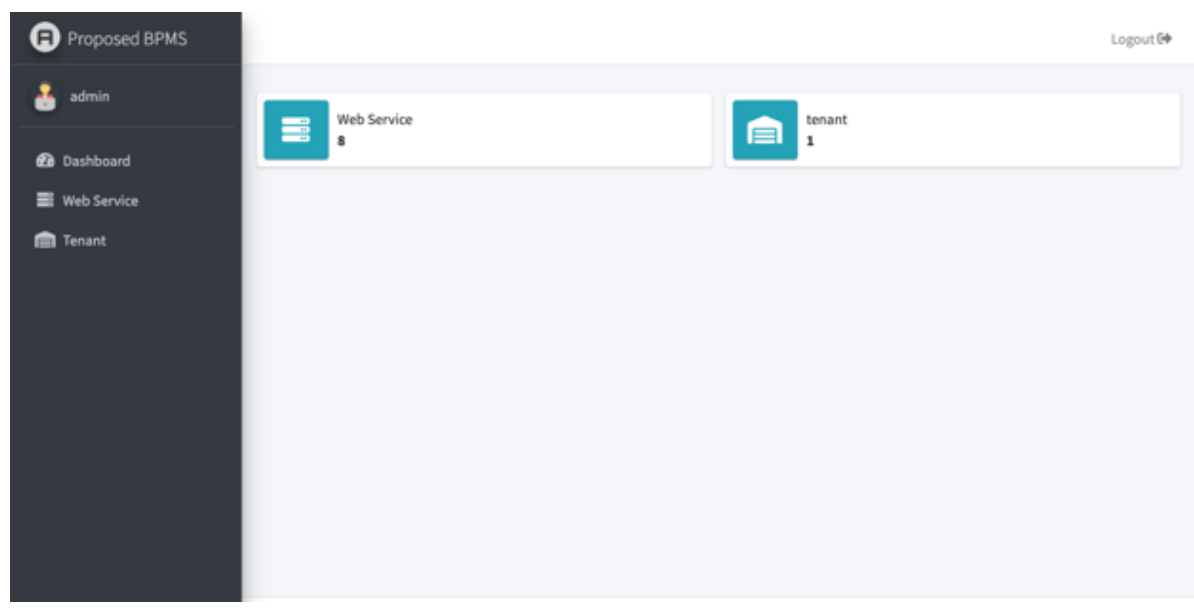

Gambar 5. Halaman Dashboard Super Admin

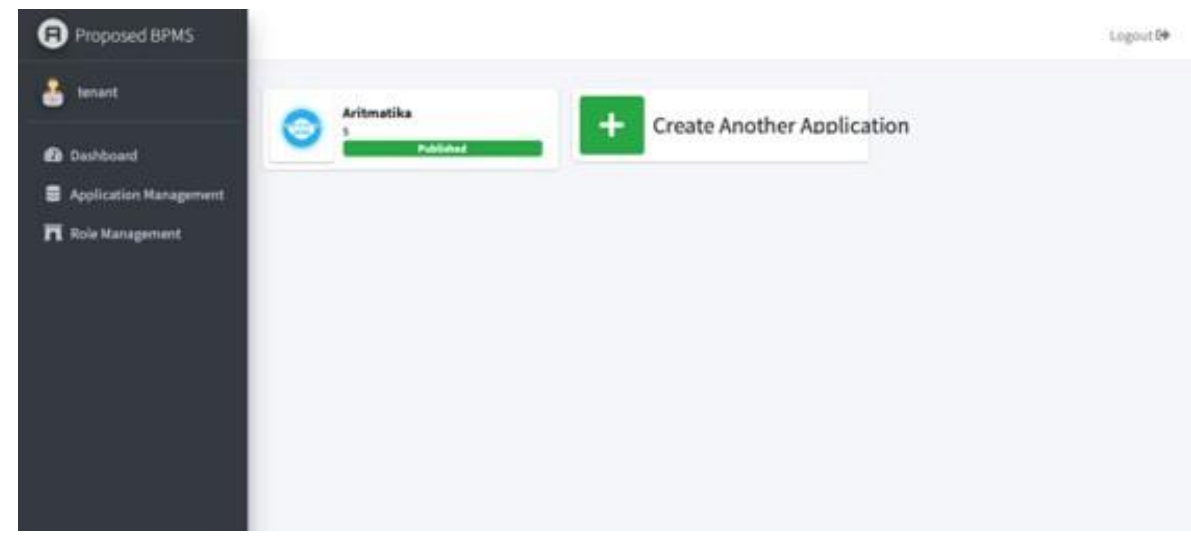

Gambar 6. Halaman Dashboard Admin Tenant

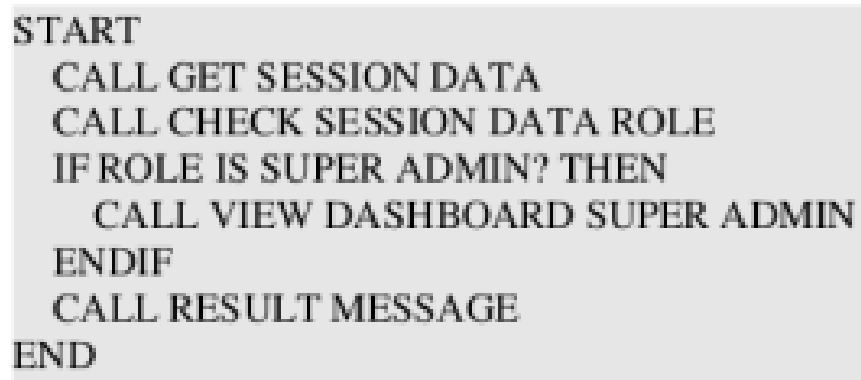

Algoritma 2. Pseudocode Pemilihan Role Super Admin 


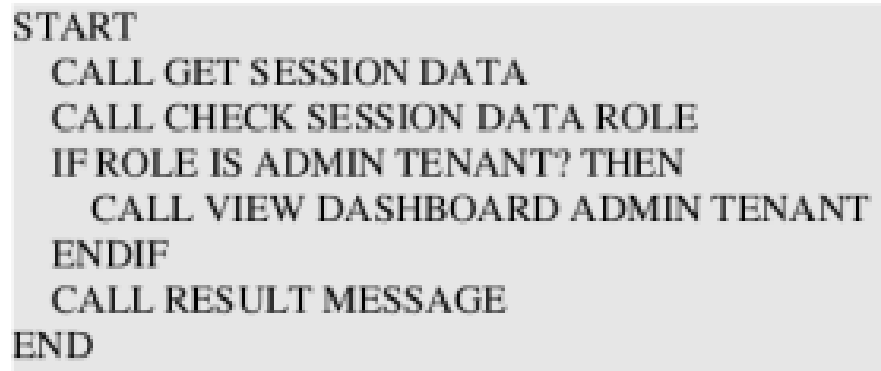

Algoritma 3. Pseudocode Pemilihan Role Admin Tenant

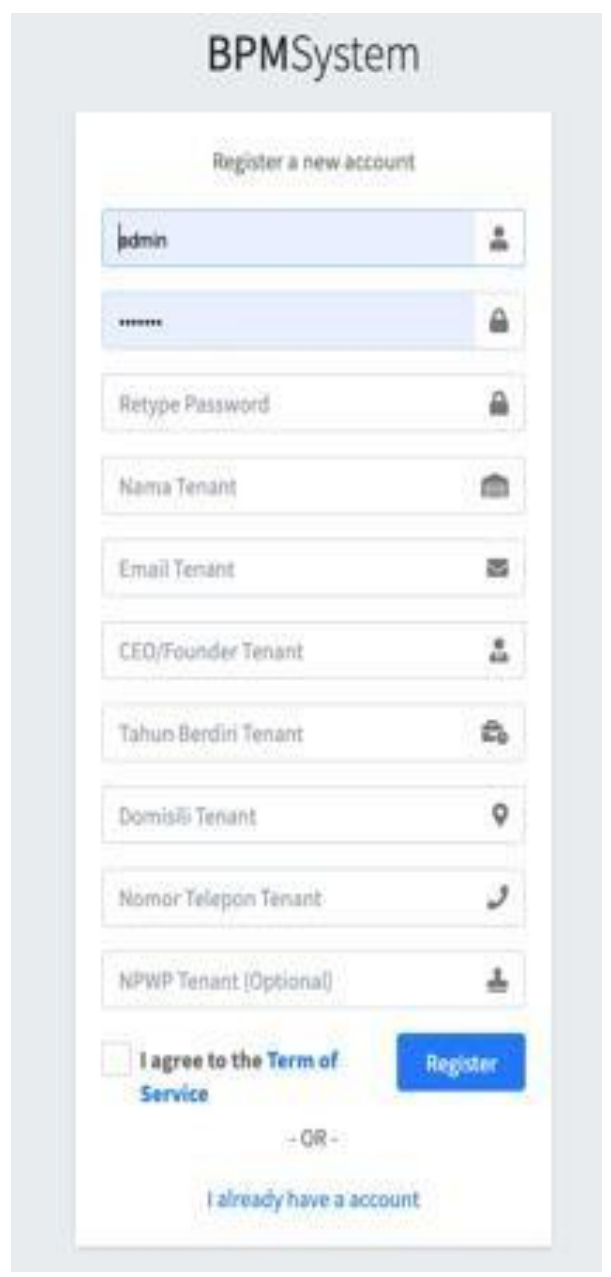

Gambar 7. Halaman Pendaftaran Tenant 


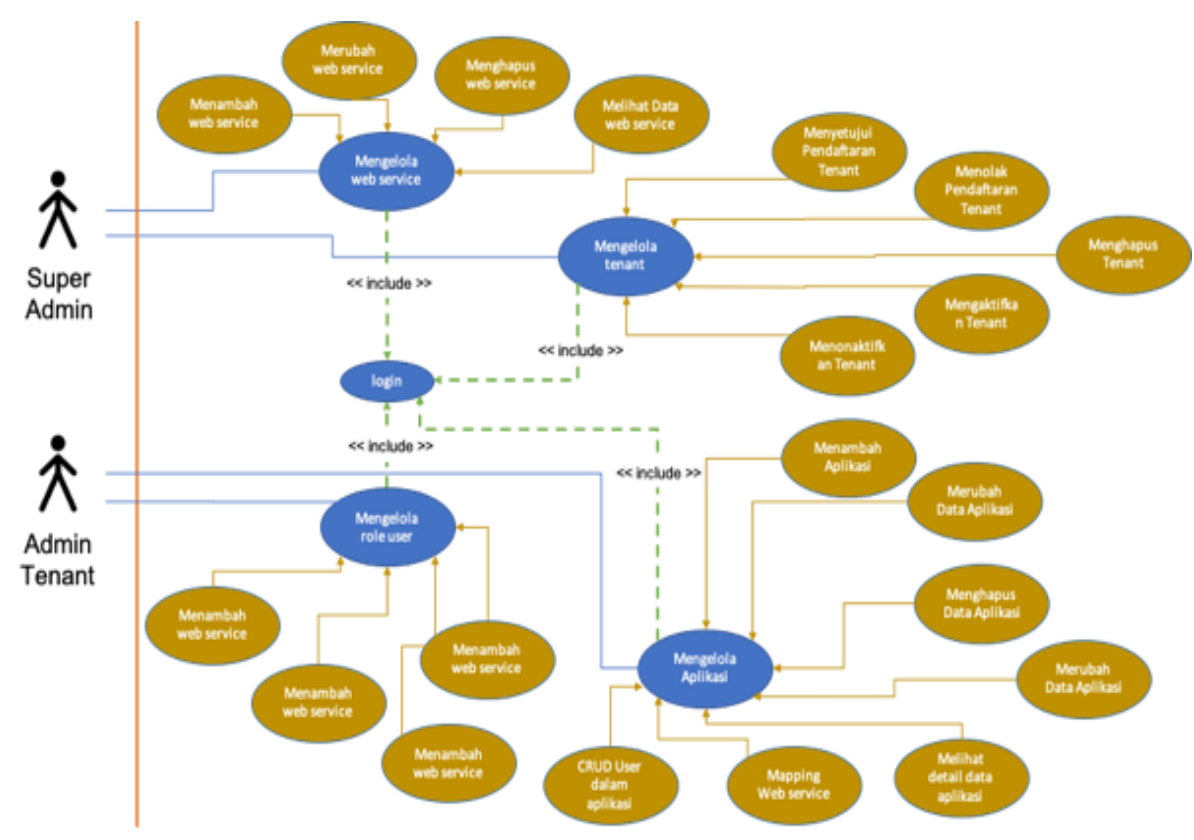

Gambar 8. Use Case Diagram

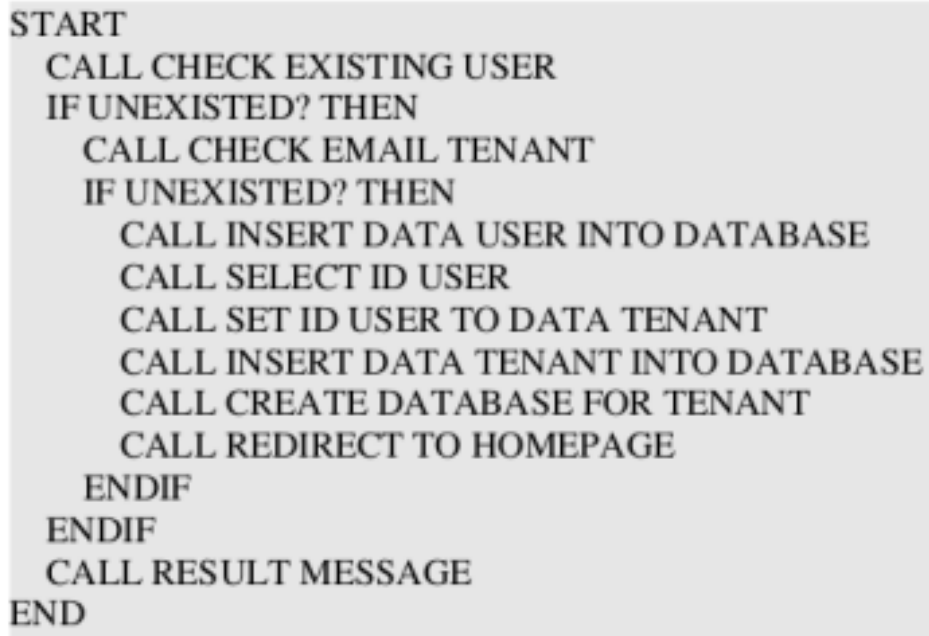

Algoritma 4. Pseudocode Pendaftaran Tenant 


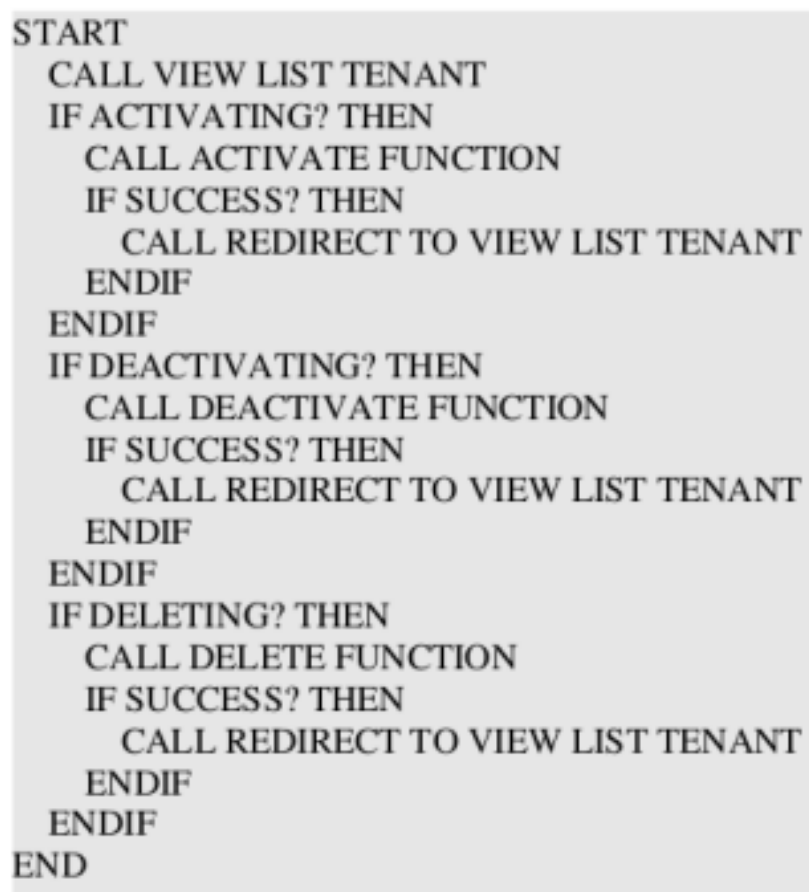

Algoritma 5. Pseudocode Manage Tenant

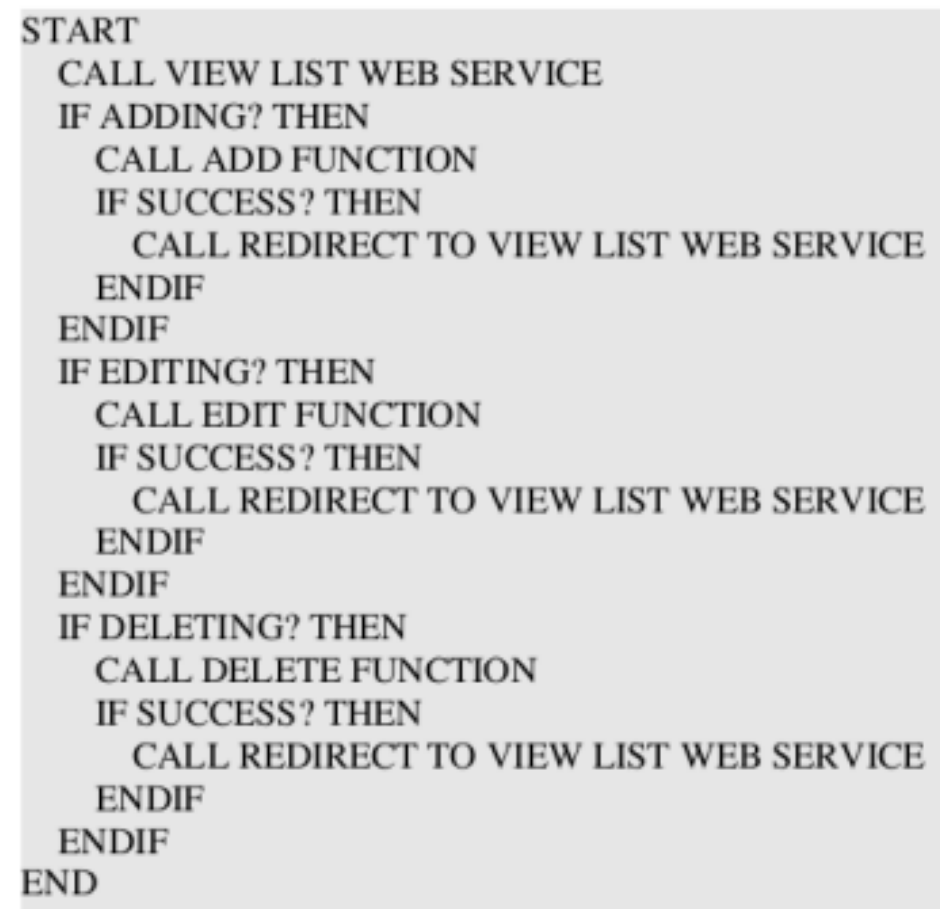

Algoritma 6. Pseudocode Manage Web Service 


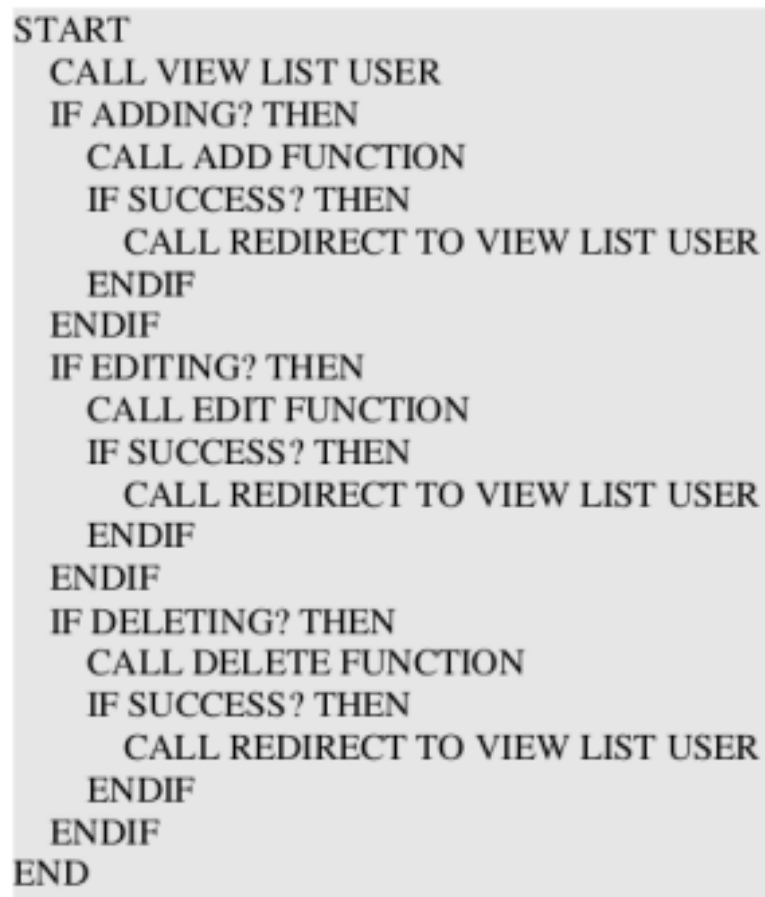

Algoritma 7. Pseudocode Manage User

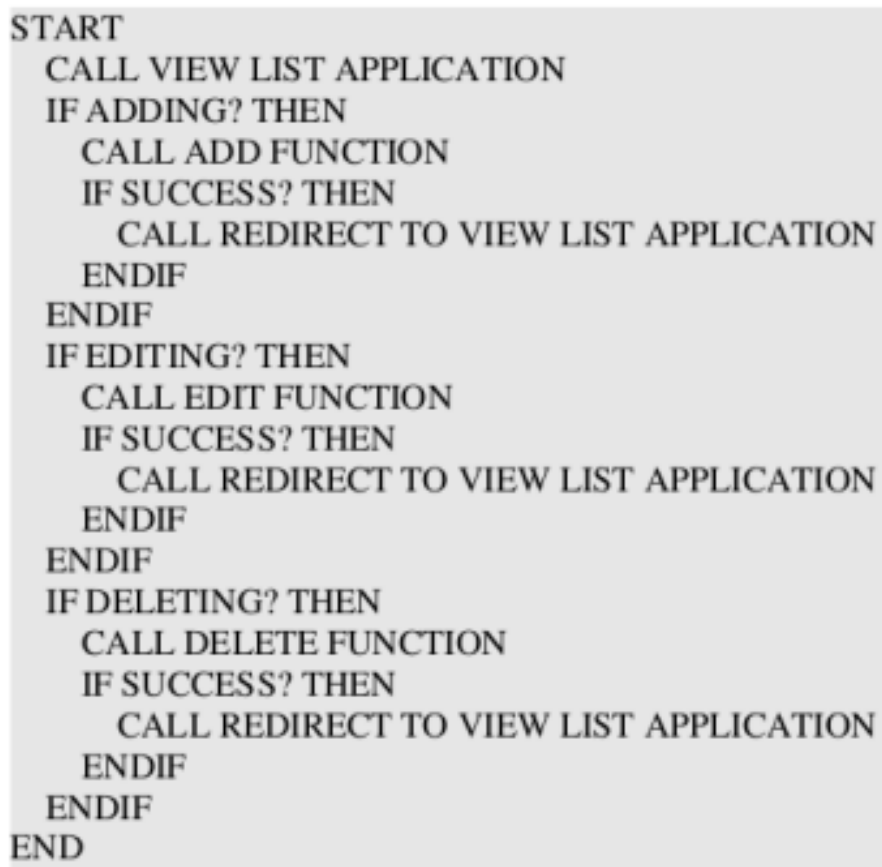

Algoritma 8. Pseudocode Manage Application 


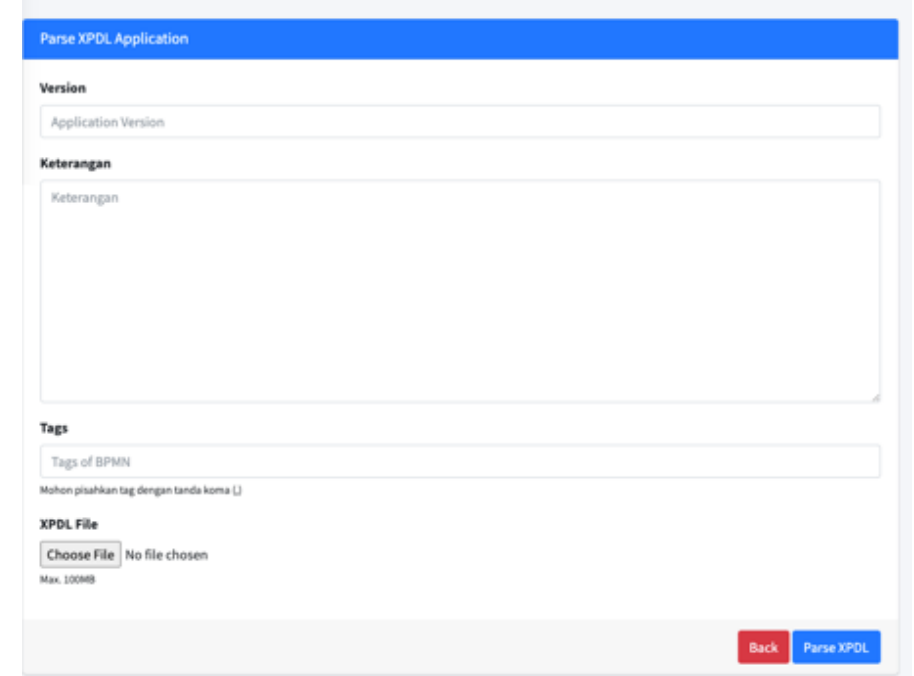

Gambar 9. Halaman Form Upload XPDL

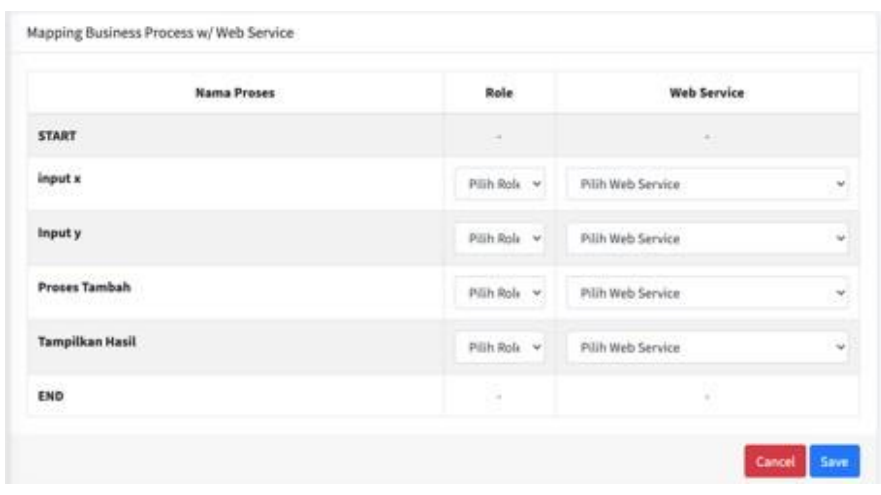

Gambar 10. Halaman Mapping Web

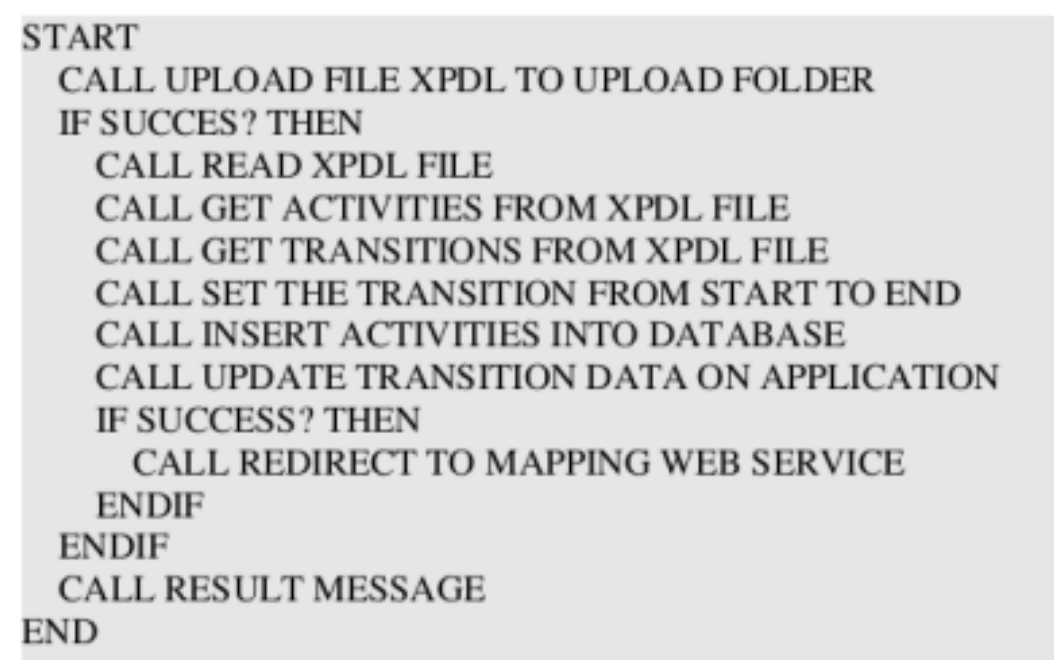

Algoritma 9. Pseudocode Parsing 


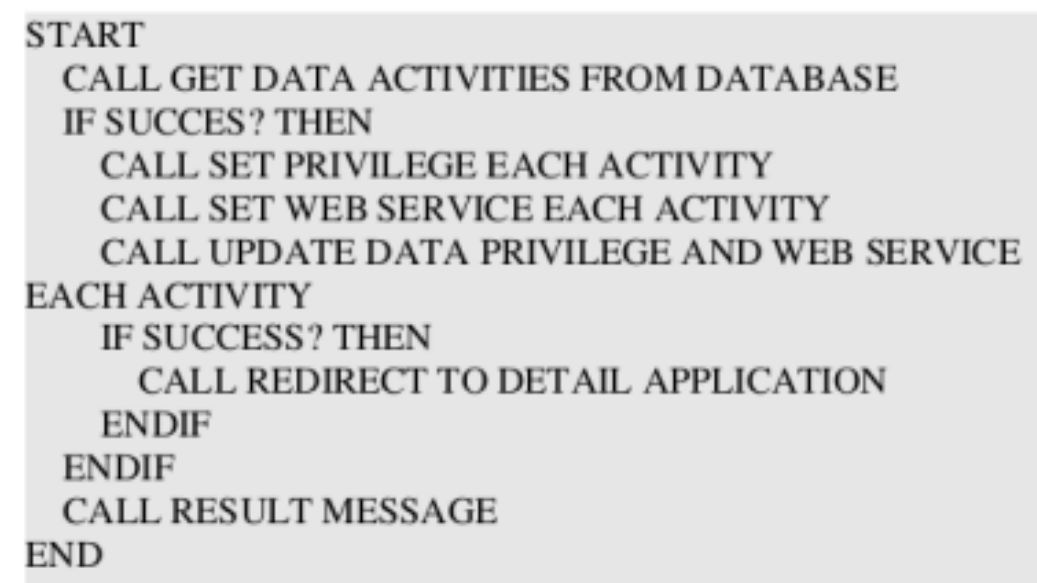

Algoritma 10. Pseudocode Mapping Web Service

Database dalam hal ini adalah perancangan basis data dari aplikasi yang dibangun. Arsitektur data yang digunakan dalam aplikasi adalah Multi-tenant. Multi-tenant adalah sebuah arsitektur yang dapat memisahkan data pada masing-masing tenant meskipun menggunakan aplikasi yang sama (Shanabrook, Glaser and Bharadwaj, 2014). Dengan begitu, data setiap tenant menjadi lebih aman. Database design dari aplikasi ditampilkan dalam gambar 11 berikut.

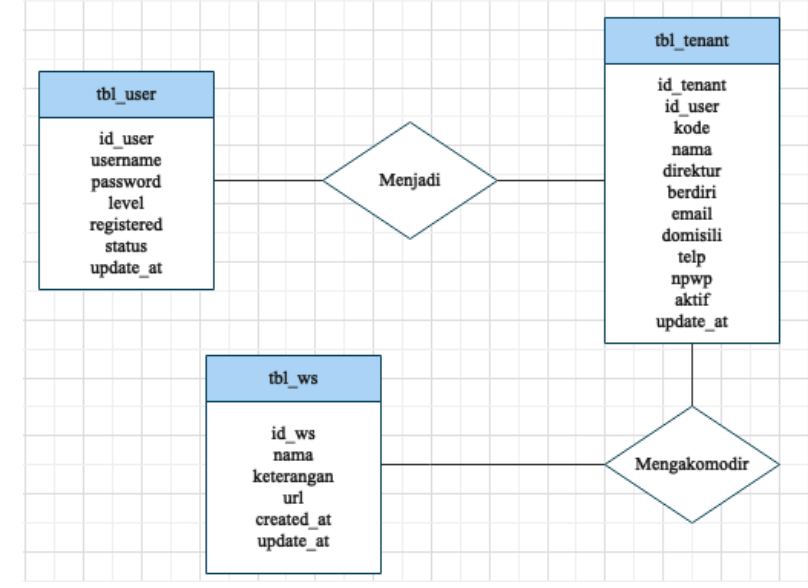

Gambar 11. ERD Database

\section{Hasil dan Pembahasan}

Pada sub bab ini akan dilakukan pengujian aplikasi berdasarkan rancangan yang telah dibuat. Pada pengujian ini menggunakan metode black box testing. Bisnis proses yang telah diekspor menjadi file XPDL yang sudah disiapkan sebelumnya menjadi bahan uji. Terdapat 2 jenis bisnis proses yaitu sequence berdasarkan gambar 2 dan branching berdasarkan gambar 3. Bisnis proses tersebut adalah perhitungan aritmatika. Alur pengujian adalah sebagai berikut:

1. Upload file XPDL

2. Parsing file XPDL

3. Mapping web service

4. Testing program

5. Validasi program 
Pada bisnis proses sequence, program berjalan dengan lancar dan hasil dari program sama dengan perhitungan secara manual. Dibuktikan dengan gambar 12 berikut.

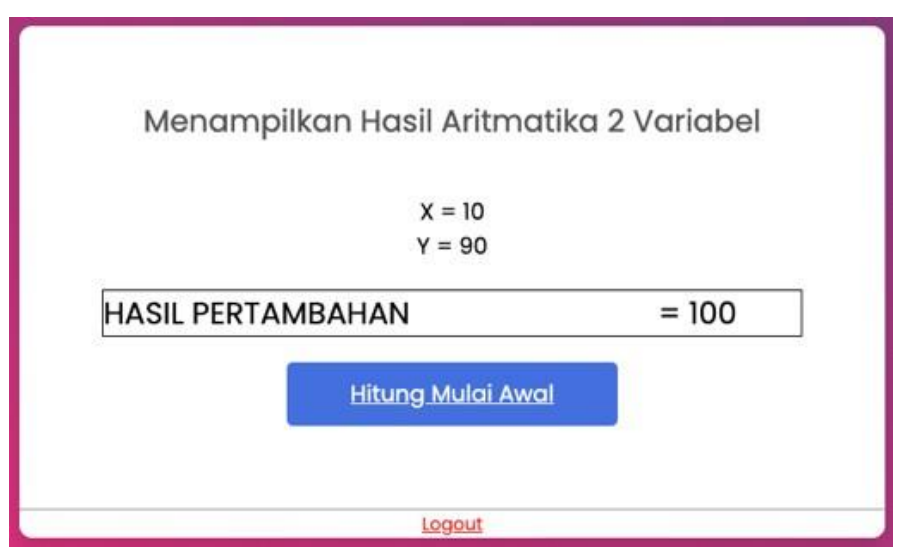

\section{Gambar 12. Hasil Bisnis Proses Squence}

Pada bisnis proses branching, program juga berjalan dengan lancar dengan pemilihan proses aritmatika yang berbeda-beda berdasarkan hak ases user masing-masing. Dibuktikan dengan gambar 13 dan gambar 14. Hasil perhitungan dari program juga sama dengan perhitungan secara manual. Dibuktikan dengan gambar 15.

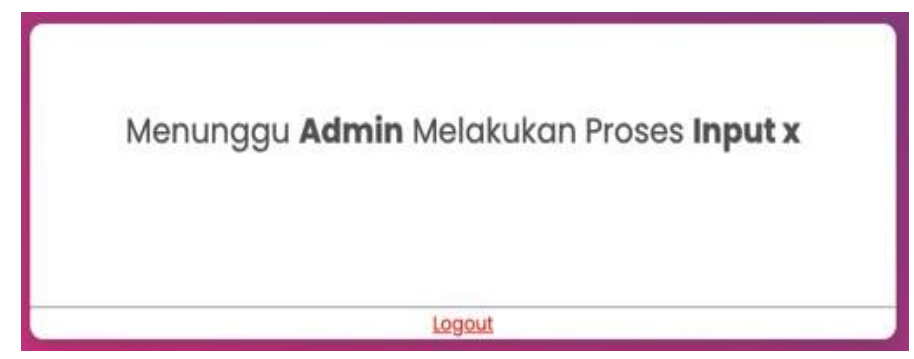

Gambar 13. Tampilan Admin2 Pada Proses Input X

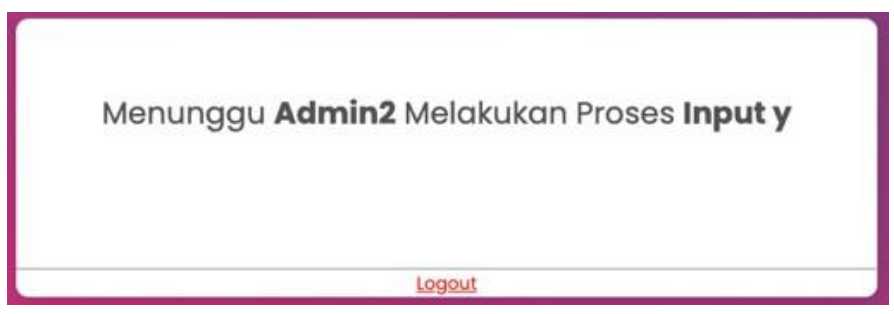

Gambar 14. Tampilan Admin Pada Proses Input Y

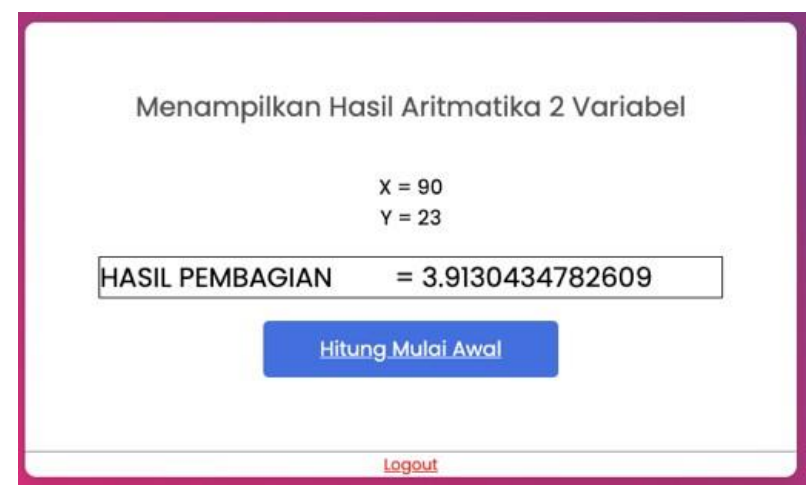

Gambar 15. Hasil Bisnis Proses Branching 
Dari hasil uji coba diatas adalah aplikasi yang dibangun dapat menjalankan program dengan 2 bisnis proses yang berbeda.

\section{Kesimpulan}

Dari hasil penelitian yang dilakukan dapat diambil beberapa kesimpulan bahwa:

1. Aplikasi mampu membedakan jenis pengguna super admin dan admin tenant.

2. Aplikasi mampu memberikan hak akses sesuai dengan jenis pengguna.

3. Aplikasi mampu melakukan parsing file XPDL serta mapping dengan web service.

4. Aplikasi mampu mengakomodasi kebutuhan web service dari program yang dibuat oleh admin tenant.

5. Aplikasi dapat menjalankan program yang dibuat oleh admin tenant berdasarkan hak akses pengguna program dengan baik.

\section{Ucapan Terima Kasih (Acknowledgement)}

Penulis sangat berterima kasih kepada seluruh tim atas kerjasamanya, khususnya kepada Bapak Ainul Yaqin dan Bapak Syahiduz Zaman selaku pembimbing yang memberikan masukan dan bimbingan sehingga bisa menyelesaikan penelitian ini.

\section{Daftar Pustaka}

Henshall, A. (2019) 9 Benefits of Business Process Management (BPM) and Why You'll Love It. Available at: https://www.process.st/benefits-of-bpm-business-process-management/ (Accessed: 15 September 2020).

Indonesia, K. P. A. N. dan R. B. R. (2020) Surat Edaran Nomor 34 Tahun 2020 dari Kementerian Pendayagunaan Aparatur Negara dan Reformasi Birokrasi RI (Kemenpan RB) tentang Perubahan atas Surat Edaran Kemenpan RB Nomor 19 Tahun 2020 tentang Penyesuaian Sistem Kerja Aparatur Sipil Negara Dalam Upaya.

Javanmard, M. and Alian, M. (2015) 'Comparison between Agile and Traditional software development', Science Journal, 36(3), pp. 43-49. Available at: http://dergi.cumhuriyet.edu.tr/cumuscij@2015\%0Ahttp://dergi.cumhuriyet.edu.tr/cumuscij.

Menteri Kesehatan Republik Indonesia (2020) Keputusan Menteri Kesehatan Republik Indonesia Nomor HK.01.07/MENKES/328/2020 Tentang Panduan Pencegahan dan Pengendalian Corona Virus Disease 2019 (Covid-19) di Tempat Kerja Perkantoran Dan Industri Dalam Mendukung Keberlangsungan Usaha Pada Situasi Pand.

Nasrullah, M., Angresti, N. D., Suryawan, S. H., \& Faizal Mahananto. (2021). Requirement Engineering terhadap Virtual Team pada Proyek Software Engineering. Journal of Advances in Information and Industrial Technology, 3(1), 1-10. https://doi.org/10.52435/jaiit.v3i1.79

Nasution, D. A. (2020) Menaker Sebut 3 Juta Pekerja Dirumahkan dan Kena PHK Imbas Corona. Available at: https://katadata.co.id/ameidyonasution/berita/5ee33f108fef5/menaker-sebut-3-jutapekerja-dirumahkan-dan-kena-phk-imbas-corona (Accessed: 10 September 2020).

Pusparisa, Y. (2020) Dampak Covid-19 terhadap Kinerja Pertumbuhan Ekonomi di Beberapa Negara. Available at: https://databoks.katadata.co.id/datapublish/2020/08/05/dampak-covid-19terhadap- kinerja-pertumbuhan-ekonomi-di-beberapa-negara (Accessed: 10 September 2020).

Shanabrook, S., Glaser, D. and Bharadwaj, N. (2014) 'Secure access to customer log data in a multitenant environment'. United State. Available at: https://patents.google.com/patent/US8713693B2/en.

TrustRadius (no date) Business Process Management (BPM) Tools. Available at: https://www.trustradius.com/business-process-management-bpm (Accessed: 15 September 2020).

Yuswohady (2020) 30 Prediksi Perilaku Konsumen di NEW NORMAL. Available at: https://www.yuswohady.com/2020/04/23/perilaku-konsumen-di-new-normal/ (Accessed: 10 
September 2020).

Zamfirescu, A. M. (2016) BonitaSoft Review. Available at: https://www.trustradius.com/reviews/bonita-bpm-2016-10-07-03-05-26 (Accessed: 15 September 2020). 